\title{
Research on Form Design of New Generation Upgrade Products Based on Brand Identity
}

\author{
$\mathrm{JN} \mathrm{Su}{ }^{1, \mathrm{a}}, \mathrm{Y} \mathrm{Lv}^{1}, \mathrm{P} \mathrm{Wang}^{1}$ and RS Bai ${ }^{1}$ \\ ${ }^{1}$ School of Design Art, Lanzhou University of Technology, 730050 Lanzhou Gansu, China
}

\begin{abstract}
The form design of new generation upgrade products based on the brand identity was studied in this paper, and the regional cultural symbols was integrated into it creatively, which provided a new way of thinking for the design of new generation upgrade products. Taking the AC contactor of Tianshui 213 as an example, firstly the consumer ' s perceptual demand and the brand identity of the products was analyzed, secondly kansei engineering theory was used to deconstruct the form of products, and then design format analysis was used to deconstruct the regional cultural symbols. Finally, the relevant design elements were combined to create a new product with regional culture and era characteristics.
\end{abstract}

\section{Brand identity and product form design under the background of regeneration}

Under the condition of economic globalization and the information network, product regeneration has become a common phenomenon in the commodity market. The iPhone has been updated to the eighth generation in just a few years since its launch. The purpose of upgrading products is to better meet the needs of the times. Under different times background, people's aesthetics and preferences often present certain differences, and also social trend style will be different. At the time when the market competition is becoming increasingly competitive, if the product is blindly conservative and do not know innovation and flexibility, it will be eliminated by the times ${ }^{[1]}$.

Under the background of product regeneration, the development of each product is a process of repeated inheritance and continuous innovation. The new and old products not only have certain connections, but also have differences. Famous companies such as Mercedes-Benz, BMW, Volvo, Danish B \& O, Apple, Sony, IBM, Philips, Italian Alessi, have always maintained a certain degree of inheritance in their products' styles during the continuous innovations. No matter how many times their products have been updated, consumers are adept at identifying them from a wide range of brands, such as Lamborghini's angular bodywork, BMW's double kidney grille and Hofmeister kink, MINI's round headlight and so on, as shown in figure 1 . In the process of product regeneration, the product form design plays an important role, it is the important content and the most obvious result of product regeneration. The form design of new generation upgrade products should not only retain the brand identity, but also conform to the trend of the times, and seek variation in the inheritance to meet the material and spiritual needs of consumers. In this paper, based on brand identity, the form design of new generation upgrade products was studied with the example of AC contactor in Tianshui 213 Electrical Apparatus Co., Ltd.

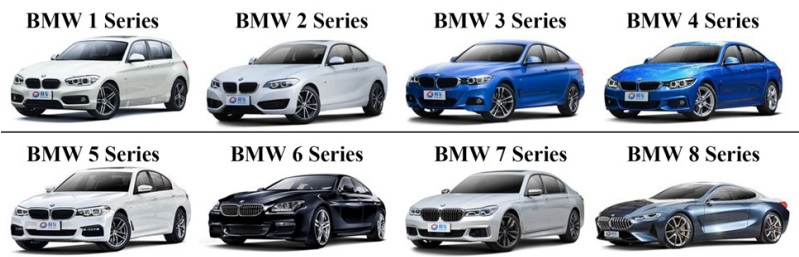

Figure 1. Brand identity of BMW Series.

\section{Positioning analysis on form design of new generation upgrade products}

The form of new generation upgrade products will change with the development of the times, which is the objective law of the evolution of new generation upgrade products. The accuracy of design positioning will directly affect the success or failure of the design and development of new generation upgrade products ${ }^{[2]}$. In the early stage of new products design, the designers need to specify the design direction through detailed positioning analysis of social demands and brand identity.

\subsection{Positioning analysis on social demand}

Social demand, which is the demand of consumer group. It is the original motivation to promote product regeneration. It can be divided into functional demand and emotional demand. Functional demand, which is the rational demand of consumers. It is the basis of product regeneration. While emotional demand refers to consumers' perceptual demand and is the orientation of

\footnotetext{
*Corresponding author: ${ }^{\text {a }}$ sujn@lut.cn
} 
product regeneration, as shown in figure 2. Baxter has pointed out that the users' needs and preferences are the main determinants of product success ${ }^{[3,4]}$.

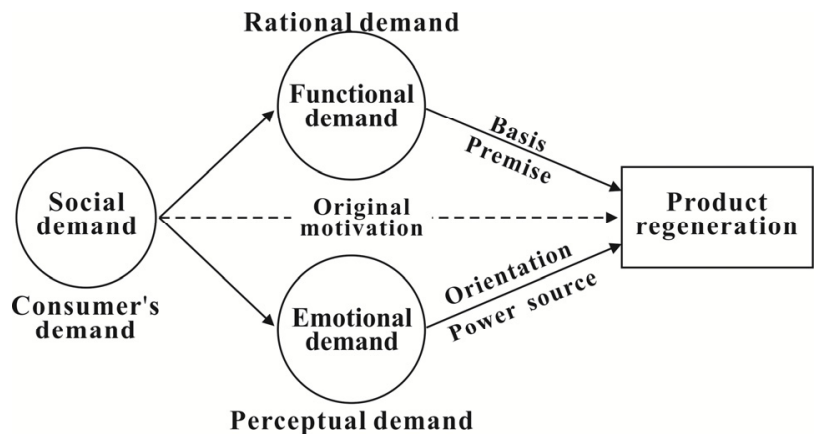

Figure 2. The relationship between social demand and product regeneration.

As far as AC contactors are concerned, consumers not only consider the functional demands of their new generation upgrade products, but also have a certain preference for their style images. Consumer's image preference vocabulary for AC contactors were obtained through previous market research, as shown in table 1 .

Table 1. Vocabulary database of kansei image for AC contactors.

\begin{tabular}{|c|c|c|c|}
\hline \multicolumn{4}{|c|}{ Vocabulary database of kansei image for AC contactors } \\
\hline Quality & Technology & Safety & Designability \\
\hline Precision & Novelty & Internationalism & Innovativeness \\
\hline Integrity & Flatness & Uniqueness & Mechanical \\
\hline Conciseness & Regularity & Progressiveness & Humanism \\
\hline Delicacy & Fashion & Harmony & Practicability \\
\hline Contemporaneity & Aesthetic & $\ldots$ & Creation \\
\hline
\end{tabular}

Through similarity analysis, four representative kansei image words were obtained: integrity, quality, technology and humanism. At the same time, consumers also have a certain demand for the cultural connotation of products. So, in the form design of regeneration for AC contactors, we can introduce regional cultural symbols to achieve the purpose of increasing the cultural connotation of new products.

\subsection{Positioning analysis on brand identity of new generation upgrade products}

In the process of form design of new generation upgrade products, only by clearly grasping the brand identity of product, can we make clear the direction of new generation upgrade products. Tianshui 213 Electrical Apparatus, which is China well-known trademark and one of the top ten brands of Chinese architectural electric. It has always been adhering to the enterprise spirit of 'harmony, loyalty, professionalism, innovation', practicing the values of 'humanity, fraternity, justice, rigor', and carrying out the business philosophy of 'quality first, customer first, law first, mutual benefit'. It also has always been dedicating to use innovation and quality to build the great wall of the safe operation of electrical system and creating a world-class electrician electrical R \& D manufacturing group. As far as the
Tianshui 213 AC contactors are concerned, consumers are impressed by its military quality and humanism. Compared with other products of the same kind, its arc shoulder shape and little curved and multi-straight form are the most obvious form features and the key to distinguish its from other brands, as shown in figure 3. Therefore, in the later regeneration design, it is necessary to extend its arc shoulder shape, little curved and multi-straight form to guarantee the brand identity.

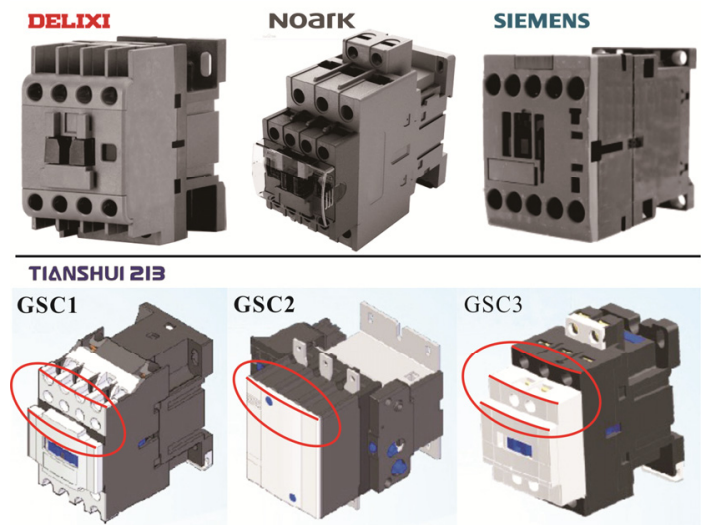

Figure 3. Brand identity of Tianshui 213 AC contactors.

\section{Form deconstruction of new generation upgrade products}

The form of the new generation upgrade products directly influences the consumers' sensory impression of it. It is an important factor for the success of the product regeneration ${ }^{[5]}$. Based on the kansei engineering theory ${ }^{[6]}$, the form deconstruction of new generation upgrade products should be started from three aspects. Firstly, through market investigation and analysis, the overall form features can be obtained. Secondly, the visual control elements of contactors' form can be obtained by using morphological analysis ${ }^{[7]}$. Thirdly, the consumers' qualitative perceptual cognition was quantified by using the quantification-I theory ${ }^{[8]}$, and the mapping relationship between the target images and the visual control elements of form was obtained to guide the development and design of new products.

\subsection{Analysis on form features of new generation upgrade products}

Different products have different functional characteristics and form features, whose functional characteristics determine the form features, and the form features reflect the functional characteristics. In the form design stage of new generation upgrade products, it is necessary for us to deeply understand the existing products and analyze the forms of them to define their form features. As far as AC contactor is concerned, it is different from other consumer products in the market. As a safety appliance for controlling load, its form features must meet certain functional requirements. By visiting the architecture electrical market, using the contactor catalogue and contactor introduction leaflet, browsing the network and other channels, we can collect the 
pictures of $\mathrm{AC}$ contactors at home and abroad to establish the sample library. The sample library was screened to remove the samples with high similarity and 26 representative samples were obtained and treated uniformly. The angle of AC contactor was to choose the squint angle (left squint / right squint), so as to show the form details of AC contactor as much as possible. At the same time, due to the color matching, nameplate, sticker and brand logo will affect the visual effect of product form in a certain extent, the $\mathrm{AC}$ contactor pictures were de-colored and information-processed, only gray space was used to indicate the difference of color matching between AC contactors. And we numbered them as shown in table 2 .

Table 2. Sample library of representative AC contactors.

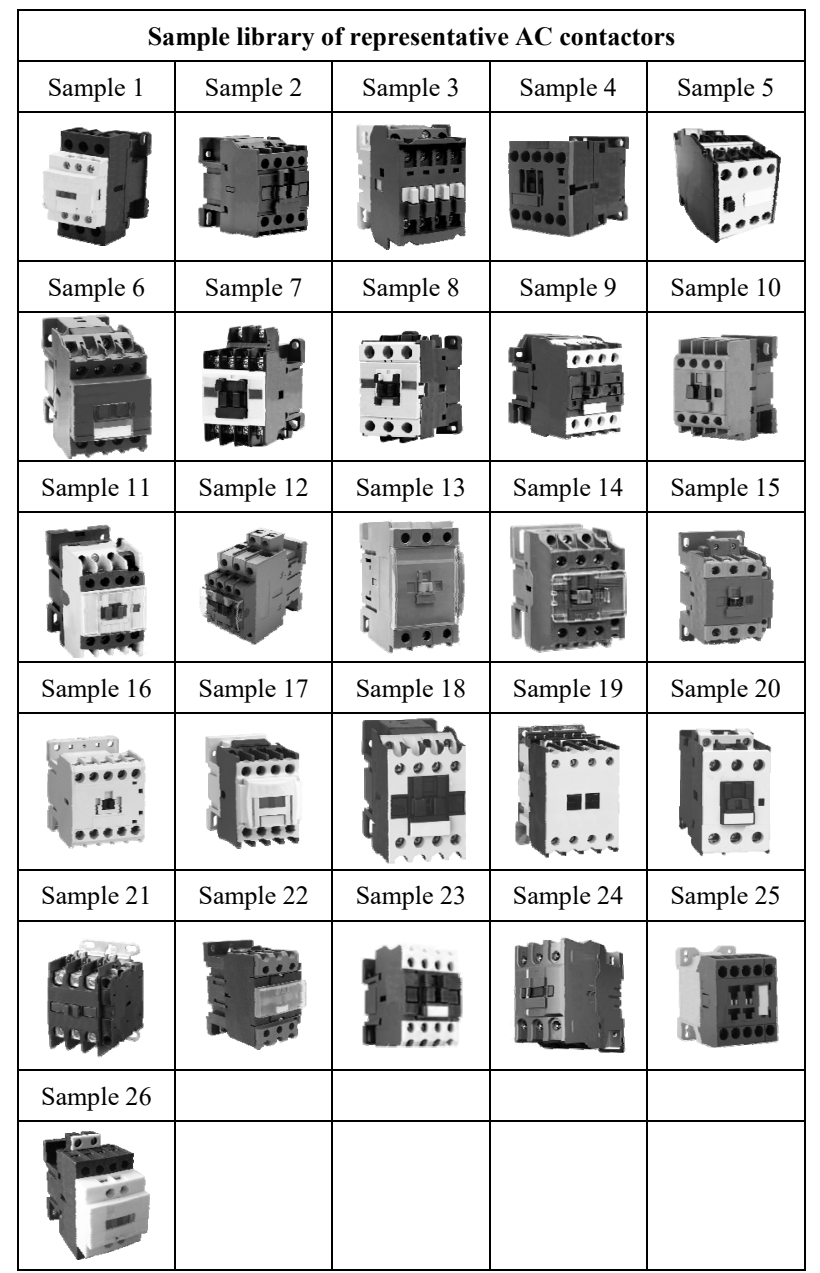

By analyzing the representative samples, we can see that the integral shape of $\mathrm{AC}$ contactors was mostly square and straight, and occasionally there were contrastive changes between small arc and large straight. But on the whole, they were biased toward square and uniform, in line with its function characteristics of high performance, high efficiency, high precision and high quality.

\subsection{Analysis on form visual control elements of new generation upgrade products}

The form visual control elements of the new generation upgrade products determine the overall form of the new generation upgrade products. Morphological analysis was used to decompose 26 representative samples, and the visual control elements (items) and classifications (catagories) of AC contactors were summarized, as shown in table 3 .

Table 3. Items and categories of AC contactor form.

\begin{tabular}{|c|c|c|}
\hline Items & Categories & Shapes \\
\hline \multirow{3}{*}{$\begin{array}{l}\text { Dust } \\
\text { cover }\end{array}$} & No dust cover & \\
\hline & Transparent dust cover & \\
\hline & $\begin{array}{c}\text { Dust cover with } \\
\text { observation window }\end{array}$ & \\
\hline \multirow{3}{*}{ Coil hole } & No countersink & \\
\hline & Round countersink & \\
\hline & Square countersink & \\
\hline \multirow{2}{*}{$\begin{array}{l}\text { Parting } \\
\text { line }\end{array}$} & Straight line & \\
\hline & Broken line & \\
\hline \multirow{3}{*}{$\begin{array}{l}\text { Contact } \\
\text { slot }\end{array}$} & No penetration type & \\
\hline & Arc penetration type & \\
\hline & Square penetration type & E \\
\hline \multirow{2}{*}{ Side slot } & Square & \\
\hline & Arc & \\
\hline
\end{tabular}

\subsection{Brand identity on form visual control elements of new generation upgrade products}

\subsubsection{Making a questionnaire}

Consumers' 4 kansei image preferences for $\mathrm{AC}$ contactors and 26 representative $\mathrm{AC}$ contactor samples in table 2 were combined. A 5-level SD questionnaire was made by using the semantic differential method ${ }^{[9]}$. Fourteen AC contactor designers and users were invited to fill out the questionnaire.

\subsubsection{Calculating the mean values of the images}

The 14 valid questionnaires were statistically analyzed to calculate the mean values of the target images of each sample. The results were shown in Table 4 .

Table 4. Mean values of target image of representative samples.

\begin{tabular}{|c|c|c|c|c|}
\hline $\begin{array}{c}\text { Samples } \\
\text { Images }\end{array}$ & Integrity & Quality & Technology & Humanism \\
\hline Sample 1 & 2.64 & 2.79 & 2.07 & 3.07 \\
\hline
\end{tabular}




\begin{tabular}{|c|l|l|l|l|}
\hline Sample 2 & 3.71 & 3.36 & 3.50 & 3.00 \\
\hline Sample 3 & 2.79 & 3.00 & 3.14 & 2.21 \\
\hline Sample 4 & 2.50 & 2.21 & 1.71 & 3.29 \\
\hline Sample 5 & 2.07 & 2.07 & 1.64 & 2.86 \\
\hline Sample 6 & 2.79 & 2.93 & 2.64 & 2.64 \\
\hline Sample 7 & 2.00 & 2.36 & 2.29 & 2.21 \\
\hline Sample 8 & 2.64 & 2.36 & 2.93 & 2.93 \\
\hline Sample 9 & 3.07 & 2.79 & 3.36 & 3.14 \\
\hline Sample 10 & 3.21 & 2.93 & 2.71 & 3.29 \\
\hline Sample 11 & 3.07 & 2.50 & 2.93 & 2.71 \\
\hline Sample 12 & 3.86 & 3.71 & 3.79 & 3.79 \\
\hline Sample 13 & 3.00 & 3.14 & 2.71 & 3.21 \\
\hline Sample 14 & 2.79 & 2.86 & 2.57 & 2.07 \\
\hline Sample 15 & 3.14 & 2.86 & 2.79 & 2.86 \\
\hline Sample 16 & 3.21 & 2.57 & 2.50 & 3.64 \\
\hline Sample 17 & 2.86 & 2.71 & 2.71 & 2.21 \\
\hline Sample 18 & 2.64 & 2.21 & 2.29 & 1.79 \\
\hline Sample 19 & 2.79 & 2.07 & 1.71 & 3.36 \\
\hline Sample 20 & 2.00 & 1.79 & 1.64 & 2.93 \\
\hline Sample 21 & 2.43 & 2.29 & 2.00 & 1.93 \\
\hline Sample 22 & 3.79 & 3.29 & 3.86 & 2.71 \\
\hline Sample 23 & 2.29 & 2.00 & 1.79 & 1.93 \\
\hline Sample 24 & 4.21 & 3.79 & 4.07 & 3.64 \\
\hline Sample 25 & 3.79 & 2.64 & 2.71 & 3.36 \\
\hline Sample 26 & 2.21 & 2.14 & 1.50 & 2.43 \\
\hline
\end{tabular}

\subsubsection{Quantifying visual control elements}

Based on the quantification-I theory, the form visual control elements of contactors were quantized, and the binary category response values were compiled, as shown in table 5 .

Table 5. Binary category response values of samples.

\begin{tabular}{|c|c|c|c|c|c|c|c|c|c|c|c|c|c|}
\hline \multirow{2}{*}{$\begin{array}{c}\text { Samples } \\
\text { Categories }\end{array}$} & \multicolumn{3}{|c|}{$\begin{array}{l}\text { Dust } \\
\text { cover a }\end{array}$} & \multicolumn{3}{|c|}{$\begin{array}{c}\text { Coil hole } \\
\text { b }\end{array}$} & \multicolumn{2}{|c|}{$\begin{array}{l}\text { Parti- } \\
\text { ng } \\
\text { line c }\end{array}$} & \multicolumn{3}{|c|}{$\begin{array}{l}\text { Contact } \\
\text { slot d }\end{array}$} & \multicolumn{2}{|c|}{$\begin{array}{l}\text { Side } \\
\text { slot e }\end{array}$} \\
\hline & $\begin{array}{l}\mathrm{a} \\
1\end{array}$ & $\begin{array}{l}\mathrm{a} \\
2\end{array}$ & $\begin{array}{l}\mathrm{a} \\
3 \\
\end{array}$ & $\begin{array}{l}\mathrm{b} \\
2\end{array}$ & $\begin{array}{l}\mathrm{b} \\
2\end{array}$ & $\begin{array}{l}b \\
3\end{array}$ & $\begin{array}{l}\mathrm{c} \\
1\end{array}$ & $\begin{array}{l}\mathrm{c} \\
2 \\
\end{array}$ & $\begin{array}{l}\mathrm{d} \\
1\end{array}$ & $\begin{array}{l}\mathrm{d} \\
2\end{array}$ & $\begin{array}{l}\mathrm{d} \\
3\end{array}$ & $\begin{array}{l}\mathrm{e} \\
1\end{array}$ & 2 \\
\hline Sample 1 & 0 & 0 & 1 & 1 & 0 & 0 & 0 & 1 & 1 & 0 & 0 & 1 & 0 \\
\hline Sample 2 & 1 & 0 & 0 & 1 & 0 & 0 & 0 & 1 & 0 & 0 & 1 & 0 & 1 \\
\hline Sample 3 & 1 & 0 & 0 & 0 & 0 & 1 & 0 & 1 & 0 & 1 & 0 & 1 & 0 \\
\hline Sample 4 & 1 & 0 & 0 & 1 & 0 & 0 & 1 & 0 & 1 & 0 & 0 & 1 & 0 \\
\hline Sample 5 & 1 & 0 & 0 & 1 & 0 & 0 & 1 & 0 & 0 & 0 & 1 & 1 & 0 \\
\hline Sample 6 & 0 & 0 & 1 & 1 & 0 & 0 & 0 & 1 & 0 & 0 & 1 & 1 & 0 \\
\hline Sample 7 & 1 & 0 & 0 & 0 & 0 & 1 & 1 & 0 & 0 & 0 & 1 & 1 & 0 \\
\hline Sample 8 & 1 & 0 & 0 & 1 & 0 & 0 & 1 & 0 & 0 & 0 & 1 & 1 & 0 \\
\hline Sample 9 & 1 & 0 & 0 & 1 & 0 & 0 & 1 & 0 & 0 & 0 & 1 & 0 & 1 \\
\hline Sample 10 & 1 & 0 & 0 & 1 & 0 & 0 & 1 & 0 & 0 & 0 & 1 & 0 & 1 \\
\hline Sample 11 & 0 & 1 & 0 & 1 & 0 & 0 & 1 & 0 & 0 & 1 & 0 & 0 & 1 \\
\hline Sample 12 & 0 & 1 & 0 & 0 & 1 & 0 & 0 & 1 & 0 & 0 & 1 & 0 & 1 \\
\hline Sample 13 & 0 & 1 & 0 & 0 & 1 & 0 & 1 & 0 & 0 & 0 & 1 & 0 & 1 \\
\hline Sample 14 & 0 & 1 & 0 & 1 & 0 & 0 & 0 & 1 & 0 & 0 & 1 & 1 & 0 \\
\hline Sample 15 & 1 & 0 & 0 & 0 & 0 & 1 & 1 & 0 & 0 & 0 & 1 & 1 & 0 \\
\hline Sample 16 & 1 & 0 & 0 & 1 & 0 & 0 & 0 & 1 & 0 & 0 & 1 & 0 & 1 \\
\hline Sample 17 & 0 & 0 & 1 & 1 & 0 & 0 & 0 & 1 & 0 & 1 & 0 & 0 & 1 \\
\hline
\end{tabular}

\begin{tabular}{|l|l|l|l|l|l|l|l|l|l|l|l|l|l|}
\hline Sample 18 & 1 & 0 & 0 & 1 & 0 & 0 & 1 & 0 & 0 & 1 & 0 & 0 & 1 \\
\hline Sample 19 & 1 & 0 & 0 & 1 & 0 & 0 & 0 & 1 & 0 & 1 & 0 & 0 & 1 \\
\hline Sample 20 & 1 & 0 & 0 & 1 & 0 & 0 & 1 & 0 & 0 & 0 & 1 & 1 & 0 \\
\hline Sample 21 & 1 & 0 & 0 & 0 & 1 & 0 & 1 & 0 & 0 & 0 & 1 & 0 & 1 \\
\hline Sample 22 & 0 & 1 & 0 & 1 & 0 & 0 & 0 & 1 & 0 & 1 & 0 & 0 & 1 \\
\hline Sample 23 & 1 & 0 & 0 & 1 & 0 & 0 & 1 & 0 & 0 & 1 & 0 & 1 & 0 \\
\hline Sample 24 & 1 & 0 & 0 & 0 & 1 & 0 & 0 & 1 & 0 & 0 & 1 & 1 & 0 \\
\hline Sample 25 & 1 & 0 & 0 & 1 & 0 & 0 & 0 & 1 & 1 & 0 & 0 & 1 & 0 \\
\hline Sample 26 & 1 & 0 & 0 & 1 & 0 & 0 & 0 & 1 & 1 & 0 & 0 & 1 & 0 \\
\hline
\end{tabular}

\subsubsection{Establishing the mapping relationship between images and visual control elements}

A computer-assisted analysis system on visual control element of product form was developed. The mapping relationships between target images and contactor visual control elements were established by using the quantification-I theory. Thus, the visual control elements of contactor form under the target images were identified, as shown in Table 6 .

In the data, the multiple correlation coefficient indicated the precision of the model, the partial correlation coefficient indicated the importance of element, the standard coefficient indicated the category's contribution value to the image. Finally, the predictions of the target images were realized, the form design of contactor's new generation upgrade products were guided.

In table 6, the multiple correlation coefficients of integrity, quality, technology and humanism were 0.70 , $0.80,0.67$ and 0.62 respectively, and their values were generally large. The results showed that the accuracy of the models is relatively high. For 'integrity', the partial correlation coefficients between parting line and side slot were 0.60 and 0.38 respectively, and the values were relatively large, which indicated that they have a great influence on the 'integrity' image of the contactors. However, the partial correlation coefficients of dust cover, coil hole and contact slot were $0.29,0.20$ and 0.16 respectively, and the values were relatively small, which indicated that these items have less influence on the 'integrity' image of the contactors. According to the standard coefficients, when the parting line was a broken line and the side slot was arc, the product image tended to 'integrity'. In view of 'quality', the parting line and coil hole had great influences on it, and the parting line should choose the broken line, and the coil hole should select the round countersink. In the view of 'technology', the parting line had great influences on it, and the parting line should be a broken line. In view of 'humanism', contact slot and parting line had great influences on it, the contact slot should be non-penetrating, and the parting line should be a broken line. In summary, when the coils hole had a round countersink, the parting line was a broken line, the contact slot was non-penetrating and the side slot was arc, the integral shape of $\mathrm{AC}$ contactors tended to integrity, quality, technology and humanism. 
Table 6. Image analysis of visual control elements in contactor form.

\begin{tabular}{|c|c|c|c|c|c|c|c|c|c|}
\hline \multirow[b]{2}{*}{ Items } & \multirow[b]{2}{*}{ Categories } & \multicolumn{2}{|c|}{ Integrity } & \multicolumn{2}{|c|}{ Quality } & \multicolumn{2}{|c|}{ Technology } & \multicolumn{2}{|c|}{ Humanism } \\
\hline & & $\begin{array}{c}\text { Standard } \\
\text { coefficient } \\
\mathrm{s}\end{array}$ & $\begin{array}{c}\text { Partial } \\
\text { correlation } \\
\text { coefficient } \\
\mathrm{S}\end{array}$ & $\begin{array}{c}\text { Standard } \\
\text { coefficient } \\
\mathrm{s}\end{array}$ & $\begin{array}{c}\text { Partial } \\
\text { correlation } \\
\text { coefficient } \\
\mathrm{s}\end{array}$ & $\begin{array}{c}\text { Standard } \\
\text { coefficient } \\
\mathrm{s}\end{array}$ & $\begin{array}{c}\text { Partial } \\
\text { correlation } \\
\text { coefficient } \\
\mathrm{S}\end{array}$ & $\begin{array}{c}\text { Standard } \\
\text { coefficient } \\
\mathrm{s}\end{array}$ & $\begin{array}{c}\text { Partial } \\
\text { correlation } \\
\text { coefficient } \\
\mathrm{S}\end{array}$ \\
\hline \multirow{3}{*}{$\begin{array}{l}\text { Dust } \\
\text { cover }\end{array}$} & $\begin{array}{c}\text { No dust } \\
\text { cover }\end{array}$ & 0.73 & \multirow{3}{*}{0.29} & 0.62 & \multirow{3}{*}{0.32} & 0.48 & \multirow{3}{*}{0.29} & 0.89 & \multirow{3}{*}{0.22} \\
\hline & $\underset{\mathrm{t}}{\text { Transparen }}$ & 2.04 & & 1.92 & & 1.61 & & 2.31 & \\
\hline & $\begin{array}{l}\text { Observatio } \\
\text { n window }\end{array}$ & 1.77 & & 1.94 & & 1.30 & & 2.24 & \\
\hline \multirow{3}{*}{$\begin{array}{l}\text { Coil } \\
\text { hole }\end{array}$} & $\begin{array}{c}\text { No } \\
\text { countersink }\end{array}$ & 0.00 & \multirow{3}{*}{0.20} & 0.00 & \multirow{3}{*}{0.50} & 0.00 & \multirow{3}{*}{0.27} & 0.00 & \multirow{3}{*}{0.13} \\
\hline & $\begin{array}{c}\text { Round } \\
\text { countersink }\end{array}$ & 0.23 & & 0.34 & & 0.22 & & 0.05 & \\
\hline & $\begin{array}{c}\text { Square } \\
\text { countersink }\end{array}$ & 0.05 & & 0.09 & & 0.40 & & -0.16 & \\
\hline \multirow{2}{*}{$\begin{array}{l}\text { Parting } \\
\text { line }\end{array}$} & $\begin{array}{l}\text { Straight } \\
\text { line }\end{array}$ & 0.00 & \multirow{2}{*}{0.60} & 0.00 & \multirow{2}{*}{0.62} & 0.00 & \multirow{2}{*}{0.48} & 0.00 & \multirow{2}{*}{0.32} \\
\hline & $\begin{array}{l}\text { Broken } \\
\text { line }\end{array}$ & 0.33 & & 0.26 & & 0.30 & & 0.16 & \\
\hline \multirow{3}{*}{$\begin{array}{c}\text { Contac } \\
\text { t slot }\end{array}$} & $\begin{array}{c}\text { No } \\
\text { penetration }\end{array}$ & 0.00 & \multirow{3}{*}{0.16} & 0.00 & \multirow{3}{*}{0.40} & 0.00 & \multirow{3}{*}{0.33} & 0.00 & \multirow{3}{*}{0.50} \\
\hline & $\begin{array}{c}\text { Arc } \\
\text { penetration }\end{array}$ & -0.10 & & -0.08 & & 0.25 & & -0.57 & \\
\hline & $\begin{array}{c}\text { Square } \\
\text { penetration }\end{array}$ & 0.02 & & 0.09 & & 0.25 & & -0.07 & \\
\hline \multirow{2}{*}{$\begin{array}{l}\text { Side } \\
\text { slot }\end{array}$} & Square & 0.00 & \multirow{2}{*}{0.38} & 0.00 & \multirow{2}{*}{0.30} & 0.00 & \multirow{2}{*}{0.23} & 0.00 & \multirow{2}{*}{0.27} \\
\hline & Arc & 0.20 & & 0.11 & & 0.15 & & 0.17 & \\
\hline \multicolumn{2}{|c|}{$\begin{array}{l}\text { Multiple correlation } \\
\text { coefficients }\end{array}$} & \multicolumn{2}{|c|}{0.70} & \multicolumn{2}{|c|}{0.80} & \multicolumn{2}{|c|}{0.67} & \multicolumn{2}{|c|}{0.62} \\
\hline
\end{tabular}

\section{Deconstruction of regional cultural symbols}

Symbols are the identifies with representative meaning and the carriers of informations. It can not only refer to things, but also express feelings and ideas ${ }^{[10]}$. Regional cultural symbols are the precious wealth of human beings, and it is also a very useful design resource in the process of form design of new generation upgrade products. If the regional cultural symbols are integrated into the form design of new generation upgrade products, it can embody the cultural connotation of the new generation upgrade products on the basis of satisfying its functions.

Tianshui 213 Electrical Apparatus is located in Tianshui, Gansu province. Tainshui Maiji Mountain Grottoes and Fuxi Temple are most well known. So the regional cultural symbols of Tianshui were deconstructed from Maiji Mountain Grottoes and Fuxi Temple. Firstly, the representative forms were integrated from of Maiji Mountain Grottoes and Fuxi Temple. Secondly, the representative forms were interpreted, and four form factors were obtained and numbered, as shown in figure 4. Finally, by using the design format analysis $^{[11]}$, as shown in figure 5 , the kansei image features of form factors were extracted, and the synthetic values of the kansei images of form factors were obtained, as shown in table 7 . The synthetic value ordering of kansei images of form factor 2, form factor 3 and form factor 4 were high, so it was suitable to integrate the cultural elements into the new generation upgrade products form design of Tianshui 213 AC contractor.

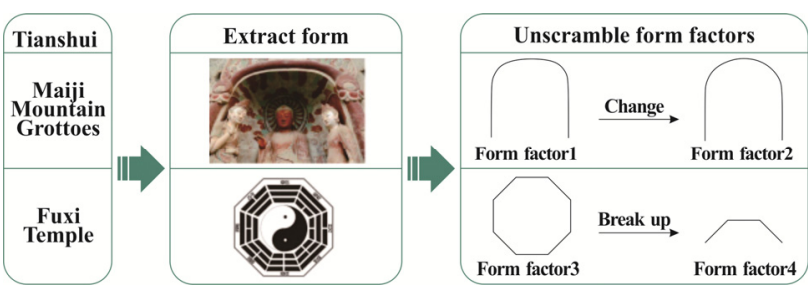

Figure 4. Capture process of regional form factors in Tianshui.

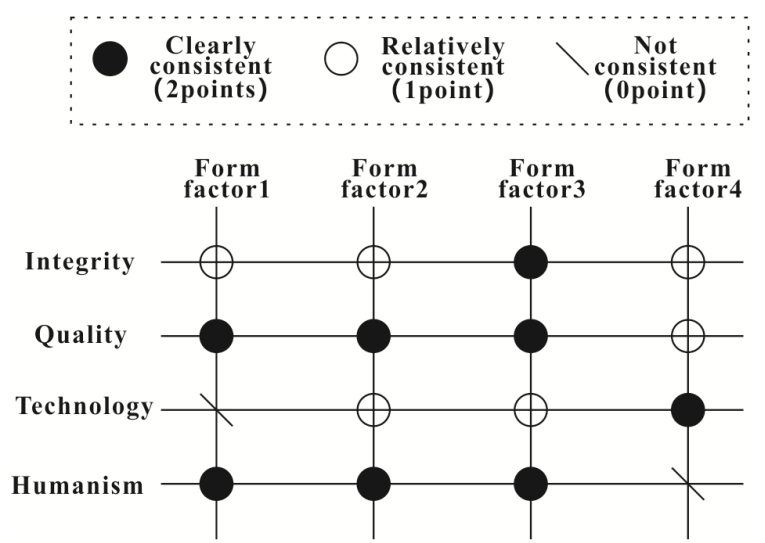

Figure 5. Diagrammatic sketch of design format analysis. 
Table 7. Mean values and synthetic values ordering of form factors to images.

\begin{tabular}{|c|c|c|c|c|}
\hline $\begin{array}{c}\text { Images } \\
\text { Form factors }\end{array}$ & $\begin{array}{c}\text { Form } \\
\text { factor1 }\end{array}$ & $\begin{array}{c}\text { Form } \\
\text { factor2 }\end{array}$ & $\begin{array}{c}\text { Form } \\
\text { factor3 }\end{array}$ & $\begin{array}{c}\text { Form } \\
\text { factor4 }\end{array}$ \\
\hline Integrity & 1.08 & 1.08 & 1.62 & 1.31 \\
\hline Quality & 1.23 & 1.46 & 1.46 & 0.92 \\
\hline Technology & 0.85 & 1.31 & 1.54 & 1.46 \\
\hline Humanism & 1.31 & 1.85 & 0.92 & 1.38 \\
\hline $\begin{array}{c}\text { Synthetic } \\
\text { values }\end{array}$ & 4.46 & 5.69 & 5.54 & 5.08 \\
\hline Ordering & \multicolumn{5}{|c|}{ Form factor $2>$ Form factor 3> Form } \\
\hline
\end{tabular}

\section{Innovative form design of new generation upgrade products}

By deconstructing the form of AC contactors, we can see that the form design of the 213 new generation upgrade AC contactor need to embody integrity, quality, technology, and humanism, and should give priority to the selection of coil hole with round countersink, broken parting line, non-penetrating contact slot and arc side slot. The form factor 2 obtained by regional cultural symbols meeted the needs of coil hole with round countersink and arc side slot. The form factor 4 meeted the form requirement of broken parting line. In summary, based on the brand identity of the 213 AC contactor, the obvious arc shoulder form was retained. Form factor 2 and form factor 4 were selectively incorporated into its form design of new generation by using the aesthetic principles, while ensuring that the integral shape was square and straight, with less curve and more straight. The new generation upgrade design was shown in figure 6 . The new product was not only brand identifiable, but also reflected the functional characteristics of $\mathrm{AC}$ contactors, and meeted the consumers' perceptual needs and cultural connotations. In addition, it also satisfied consumers' perceptual needs.
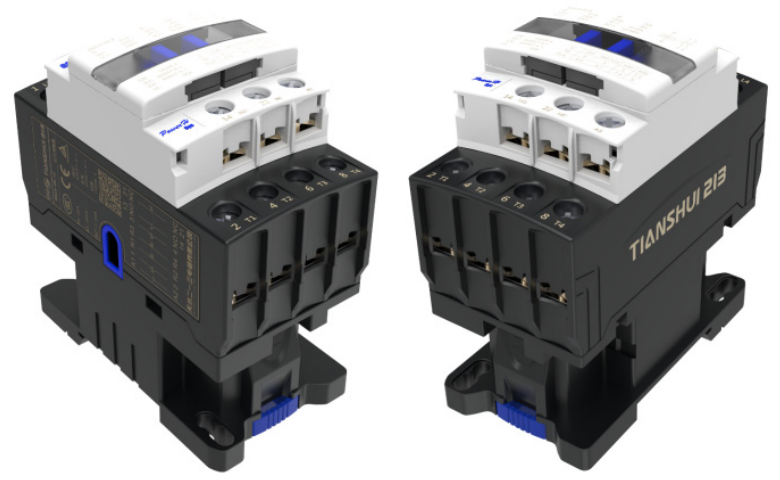

Figure 6. New generation upgrade design of 213 AC contactor.

\section{Conclusion}

The product regeneration conforms to the pace of the development of the times, and it overcomes the restriction of the product life cycle. Under the circumstance of the decline of the previous generation products, the new product will go back to the starting point of the life cycle. Based on brand identity, this study integrated regional cultural symbols into the form design of new generation upgrade product. It endowed the new product with certain cultural connotation, and made the new generation upgrade product form design have rules to follow. Designers should firmly grasp the pulse of the times and timely transform the functions, ideas, emotions and connotations of the brand into the form elements of the new products, to communicate the specific images for users and creat the new products which accord with the trend of the times and have national characteristics. The new products will make consumers get the aesthetic experience and spiritual satisfaction, so as to ultimately obtain design recognition, which can not only deepen the impression of the brand, but also guarantee the long-term heritage of the brand.

\section{Acknowledgments}

The authors would like to extend our sincere thanks to all those who contributed to this study, especially the participants who took the trouble to respond to the questionnaires. The project is sponsored by National Natural Science Foundation of China (51465037), Hongliu Outstanding Talent Development Program of Lanzhou University of Technology (J201406) and New Generation Series Products Appearance Industrial Design of Tianshui 213 Electrical Apparatus (H1707cc006).

\section{References}

1. M Xu, JC Lv, W Li, YK Wu. Strategies and Methods of Car Form Design in the Background of Cars Regeneration. South Agricultural Machinery, 48, 15, 138+145 (2017)

2. JH Hu. Orientation Views of Product Design. Packaging Engineering, 22, 6, 77-78 (2001)

3. M Baxter. Product design-practical methods for the systematic development of new products (Stanley Thornes Ltd, Cheltenham, 1995)

4. JN Su, HQ Li, FQ Li. Investigation of kansei image direction for product design. Journal of Lanzhou University of Technology, 30, 2, 40-43 (2004)

5. XW Li. Strategies and Methods of Car Styling Design in the Background of Cars Regeneration. Journal of Wuhan University of Technology (Social Sciences Edition), 29, 2, 308-313 (2016)

6. K Yamamoto. Kansei Engineering: The Art of Automotive Development at Mazda (The University of Michigan, Ann Arbor, 1986)

7. DY Li. Introduction of Design Format Analysis in Product Design. Tianjin Textile Science \& Technology, 41, 2, 26-28 (2004)

8. JN Su, HQ Li. Investigation of relationship of form design elements to kansei image by means of 
quantification-I theory. Journal of Lanzhou University of Technology, 31, 2, 36-39 (2005)

9. CE Osgood, CJ Suci, PH Tannenbaum. The measurement of meaning (University of Minoes Press, Urbana, 1957)

10. SJ Luo, WJ Li. Product Family Design DNA (China Architecture \& Building Press, Beijing, 2016)
11. P Oscar, S Jan, S Dirk. Should new products looks imilar or different? The influence of the Market environment on strategic product styling. Design Studies, 29, 1, 30-48 (2008) 